\title{
Dynamics of Growth of the Introduced Nectarine
}

\section{Cultivars}

\author{
Dimitar Dimitrov Vassilev \\ Experimental Station of Agriculture, Khan Krum, Shumen 9863, Bulgaria
}

\begin{abstract}
A research on the topic was conducted at the Experimental Station of Agriculture-Khan Krum during the period 2009-2011. The dynamics of growth and thickening of the cultivars Independence, Nectagrand 2, Aureliogrand, Fantasy, Kassiopeia and Caldessi 2000 grafted on seedling rootstock (Elbert) and clonal GF-677 have been studied in the second year of nursery. The aim of the study was to investigate the growth characteristics of the introduced cultivars of nectarines grafted on traditional seedling rootstock (Elbert) and GF-677. At the beginning of the vegetation period of the seed cultivar rootstock (Elbert) has strong growth and thickening of the stem. The dynamics of growth and thickening of the stem depend on the used rootstock and cultivar. The obtained planting material corresponds to the existing quality standards.
\end{abstract}

Key words: Rootstocks, cultivars, nectarines, grafted.

\section{Introduction}

The selection of rootstock is becoming increasingly difficult as a result of the availability of numerous new rootstocks.

Peach and nectarine cultivars grafted on clonal rootstock GF-677 is characterized by stronger growth, larger fruitfulness, late maturity and high yield compared to the widely used seedling rootstock [1-3].

According to Motisi et al. [4] fruit quality of cultivar Rich May with rootstock GF-677 has a larger variation.

According to Remorini et al. [5] medium strength rootstocks determine a better quality of fruit peach compared to the strong growing.

Beckman et al. [6] tested peach cultivar Krestheyvan of rootstocks Guardian and Nemagard. Propagating materials of the rootstock have high cumulative yield, while the grafting of Lovell is distinguished by relatively low yield.

Loreti and Massai [2006] determined that when choosing a rootstock to create a new orchard, cultivars

Corresponding author: Dimitar Dimitrov Vassilev, Ph.D., research field: fruit growning and agrotechnics. E-mail: dimi_a@abv.bg. that are resistant to abiotic (low winter temperatures, active lime, soil pathogens, drought and water logging of the soil) and biotic (nematodes, fungi and bacteria) factors should be preferred.

Over the past few years traditionally used rootstocks in peach production have increasingly cut clonal rootstock GF-677. That is why the aim of the present work is to study the dynamics of growth in some introduced nectarine cultivars.

\section{Material and Methods}

Studies on the topic were conducted in the period 2009-2011 at the Experimental Station of Agriculture-Khan Krum. An experiment was set with three replications in five trees from cultivar-rootstock combinations. Fruit Nursery is under irrigation. Nectarine cultivars Independence, Nectagrand 2, Aureliogrand, Fantasy, Kassiopeia and Caldessi 2000 grafted on seminal (Elbert) and clonal GF-677 rootstock were tested in the second year of nursery. The clonal rootstock was obtained from the Fruit growing Institute-Plovdiv. Rootstocks were planted at a distance $80 / 12 \mathrm{~cm}$ in the middle of March.

Grafting was performed on a dormant bud in August by the method of T-shaped cut. During the 
vegetation growth in the trees 20 plants of the cultivar-rootstock combination were measured in 10 days period. The thickness of the stem was measured with a micrometer at the height of $15 \mathrm{~cm}$ from the point of grafting.

A statistical analysis was made using the criteria of Dunkan [7].

\section{Results and Discussion}

Table 1 presents data on the height and thickness of the rootstock combinations measured at the end of the growing season. Cultivars Kassiopeia, Nectagrand 2 and Caldessi 2000 [178.9-187.3] have distinguished from plants with proven highest seedling rootstock. Fantasy and Aureliogrand are characterized by relatively low trees [153.0-156.4].

The thickness of the trees is an important indication which depends on the quality of the planting material. The thickness of the grafted cultivars of seedling rootstock varied from 13.6 to $17.0 \mathrm{~mm}$. It is obvious that Nectagrand 2, Caldessi 2000, Kassiopeia and Idependence [14.5-17.0] have thicker stems. Aureliogrand and Fantasy were proved to have the lowest values.

When these cultivars are grafted on clonal rootstock GF-677, height varies from 159.3 to $189 \mathrm{~cm}$. Aureliogrand, Caldessi 2000 and Nectagrand 2 were characterized with proven higher plants. Relatively low plants are Fantasy and Independence [159.3-166.9 cm].
The thickness of the examined cultivars was in the range from 14.4 to $16.5 \mathrm{~mm}$. Relatively high values are cultivars Aureliogrand, Independence and Kassiopeia 15.8-16.5 mm. With the lowest values of this indicator cultivar Fantasy is characterized.

Figure 1 presents the dynamics of growth and thickening of the stem. At the beginning of the vegetation period of seed cultivar rootstock (Elbert) have strong growth and thickening of the stem. In Aureliogrand, Nectagrand 2 and Fantasy equalization of the pace of growth and thickening of the seminal (Elbert) and clonal rootstock GF-677 was observed. After that the grafting rootstocks GF-677 had superiority and were characterized by strong growth. Kassiopeia cultivar is characterized by strong growth and thickening of the stem when grafted on seedling rootstock. Caldesi 2000 grew strongly at the height of the seedling rootstock and grafted thickness when GF-677 Independence had taller plants on rootstock GF-677 and stronger thickening of the stem on seminal rootstock.

\section{Conclusions}

At the beginning of the vegetation period of seed cultivars rootstock (Elbert) has strong growth and thickening of the stem.

The dynamics of growth and thickening of the stem depend on the used rootstock and cultivar.

The obtained planting material corresponds to the existing quality standards.

Table 1 Size of the obtained trees in the second year of nursery.

[average for the period 2009-2011]

\begin{tabular}{llllc}
\hline & \multicolumn{3}{c}{ Rootstocks } \\
\cline { 2 - 5 } Cultivars & \multicolumn{3}{c}{ Seminal } & INRA GF 677 \\
\cline { 2 - 5 } & Height, cm & Thickness, mm & Height, cm & Thickness, mm \\
\hline Aureliogrand & $156.4 \mathrm{e}$ & $13.6 \mathrm{~d}$ & $179.0 \mathrm{c}$ & $15.8 \mathrm{c}$ \\
Nectagrand 2 & $181.6 \mathrm{~b}$ & $14.5 \mathrm{~b}$ & $189.6 \mathrm{a}$ & $15.4 \mathrm{~d}$ \\
Independence & $164.4 \mathrm{~d}$ & $17.0 \mathrm{a}$ & $166.9 \mathrm{~d}$ & $16.0 \mathrm{~b}$ \\
Fantasy & $153.0 \mathrm{e}$ & $14.1 \mathrm{c}$ & $159.3 \mathrm{e}$ & $14.4 \mathrm{e}$ \\
Caldesi 2000 & $187.3 \mathrm{a}$ & $14.9 \mathrm{~b}$ & $184.9 \mathrm{~b}$ & $15.4 \mathrm{~d}$ \\
Kassiopeia & $178.9 \mathrm{c}$ & $16.8 \mathrm{a}$ & $176.1 \mathrm{c}$ & $16.5 \mathrm{a}$ \\
LSD 5\% & 2.3 & 0.4 & 4.0 & 0.1 \\
\hline
\end{tabular}



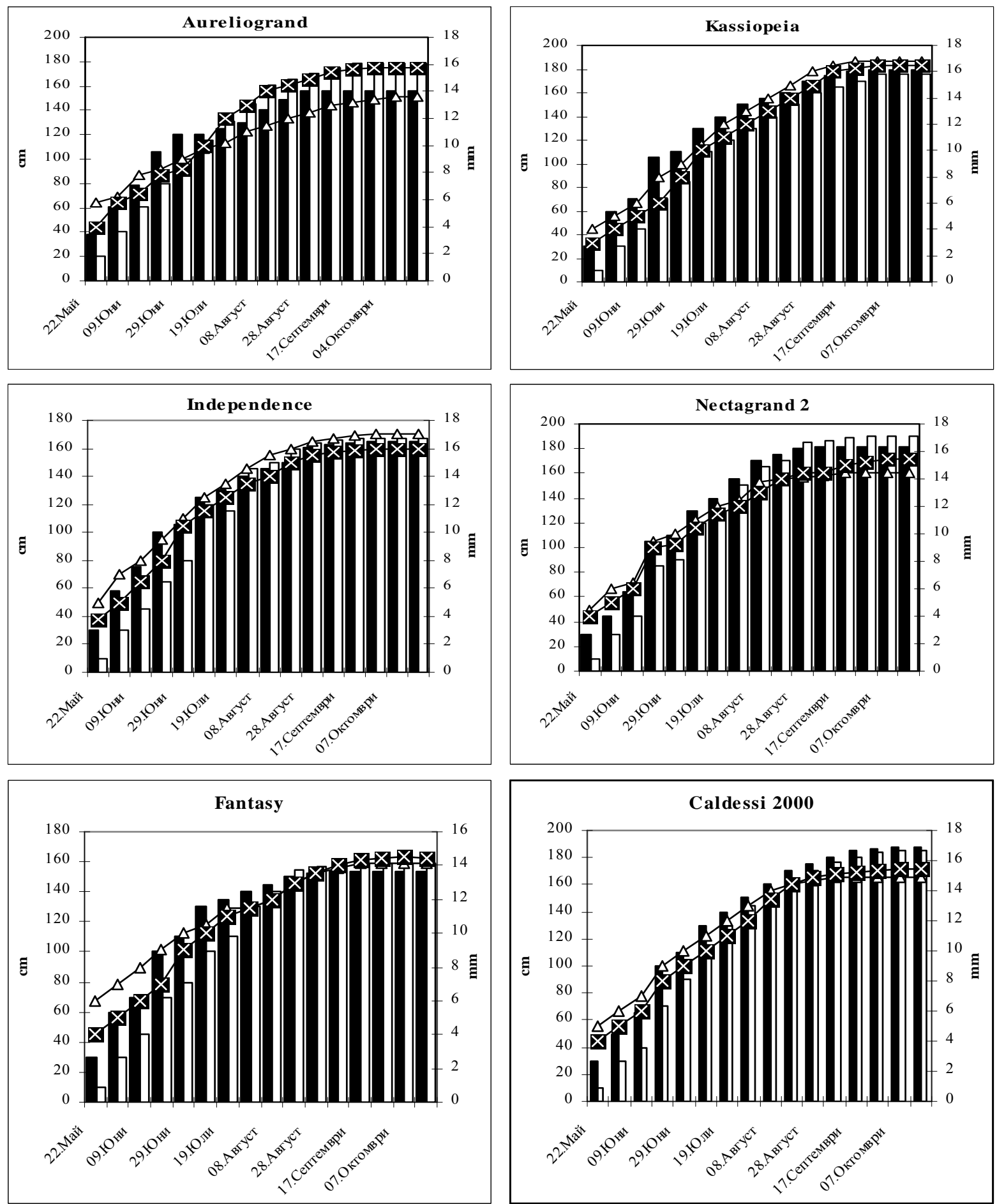

Height of the seminal rootstock.

$\downarrow$ Height of the GF-677.

$\triangle$ Thickness seminal rootstock

Thickness of the stem GF-677.

Fig. 1 Dynamics of growth and thickening of the stem. 


\section{References}

[1] Bozkova, V., Rankova, Z., and Milucheva, S. 2012. "Study of Peach Cultivars to Project for Development of Orchard Farm." Agriculture Plus 3: 34-5.

[2] Motisi, A., Marra, F., Penice, F., Caruso, T., Gulo., G., Mafrica., R., and Zappia., R. 2006. "Relationship between Canopy Architecture and Fruit Quality on Rich may Peach Grafted onto Penta and GF 677 Rootstocks." Acta Horticulture [ISHS] 713: 365-72.

[3] Schmid, H., Obstbaumschnitt K., and Steinobst, B. 2003. Ulmer 203: 16-20.
[4] Remorini, D., Loreti, F., and Masai, R. 2006. "Determination of Maturity Stage and Fruit Quality in Peach by Skin's Optical Properties." Acta Horticulture [ISHS] 713: 471-8.

[5] Beckman, T., A., and Nyszepir, S. Meyers. Performance of Peach. "Rootstocks Propagated as Seedlings vs. Cultivars." Acta Horticulture [ISH] 713: 294-8.

[6] Loreti, F., and Massai, R.. "State of the Art on Peach Rootstocks and Orchard Systems." Acta Horticulture [ISHS] 713: 253-68.

[7] Lidanski, T. 1988. "Statistical Methods in Biology and Agriculture." Zemizdat 374: 323-6. 